\title{
How Does Financial Development Impact Economic Growth in Pakistan?: New Evidence from Threshold Model
}

\author{
Rameez TARIQํㅜ, Muhammad Arshad KHAN², Abdul RAHMAN ${ }^{3}$ \\ Received: June 10, 2020 Revised: June 28, 2020 Accepted: July 12, 2020
}

\begin{abstract}
This study examines the nonlinear relationship between financial development and economic growth in Pakistan using the threshold regression model for the period 1980-2017. We also employed quantile regression with 0.25 , 0.50 , and 0.75 quantiles of conditional distribution. The quantile regression is based on minimizing of sum of squared residuals. The result indicates that economic growth responds positively to financial development when the level of financial development surpasses the threshold value of 0.151 . However, when financial development lies below the threshold value (that is, 0.151 ), its impact on economic growth is negative. Thus, when financial development of Pakistan surpasses the threshold level, it contributes more towards economic growth since greater level of financial development contributes more to boosts economic growth. This finding reveals that economic growth reacts differently to financial development, and the relationship between financial development and economic growth is U-shaped in Pakistan. Among the other variables, physical capital, labor force, and government expenditure exert a positive effect on economic growth. Furthermore, inflation rate and trade openness have an insignificant impact on economic growth. The results of quantile regression also confirm the non-linear relationship between financial development and economic growth in Pakistan. The finding of this study suggests revamping of financial sector policies in Pakistan.
\end{abstract}

Keywords: Finance-Growth Nexus, Threshold, Non-linearity, Quantile Regression

JEL Classification Code: C21, C24, F43, O47

\section{Introduction}

Financial development deals with the policies, processes, and strategies to enhance the financial access, depth, and efficiency of the financial institutions and financial markets. A well-developed financial system enhances economic efficiency by channeling scarce resources to the most

${ }^{1}$ First Author and Corresponding Author. PhD Scholar, Department of Management Sciences, COMSATS University, Islamabad, Pakistan [Postal Address: Park Road, Islamabad, Islamabad Capital Territory 45550, Pakistan] Email: rameeztariq20@yahoo.com

${ }^{2}$ Associate Professor and Chairman, Department of Economics, COMSATS University, Islamabad, Pakistan.

Email: arshad.khan@comsats.edu.pk

${ }^{3} \mathrm{PhD}$ Scholar, Department of Management Sciences, COMSATS University, Islamabad, Pakistan.

Email: rehmansargodha@yahoo.com

(c) Copyright: The Author(s)

This is an Open Access article distributed under the terms of the Creative Commons Attribution Non-Commercial License (http://Creativecommons.org/licenses/by-nc/4.0/) which permits unrestricted noncommercial use, distribution, and reproduction in any medium, provided the original work is properly cited. efficient uses that lead to sustainable growth (Slesman, Baharumshah, \& Azman-Saini, 2019). The impact of finance on growth has been at the center of most policy debates among the researchers over the past few decades (Ang \& McKibbin, 2007; Seven \& Yetkiner, 2016). Theoretical literature suggests that financial development can promote economic growth through the pooling of savings, risk reduction and risk management, facilitation of exchange via reduction of transaction costs, information sharing about investment opportunities, improvement of capital allocation, and the increase of investor's willingness to finance new projects through monitoring corporate governance (King \& Levine, 1993; Levine, 2005).

Most of the empirical literature (for example, King \& Levine, 1993; Levine, 1998) concluded that there is a positive relationship between finance and growth, while Fisman and Love (2002) and Demirgus-Kunt and Maksimovic (2002) documented similar relationship at industry and firm-levels, respectively. Notwithstanding, finance-growth literature predicted four possible directions. First, finance is an engine of economic growth (Schumpeter, 1912; McKinnon, 1973; 
Shaw, 1973; Levine, 2005). They considered savings and investments, and allocation of funds to productive sectors as important channels through which efficiency of capital increases, which in turn enhances economic growth (AlYousif, 2002; King \& Levine, 1993; Masten, Coricelli, \& Masten, 2008). Second, economic growth drives the demand for financial services, which in turn positively impacts financial development (Robinson, 1952; Demetriades \& Hussein, 1996; Panizza, 2012). Third, causality in the finance-growth nexus is bi-directional. The majority of studies (for example, Greenwood \& Smith, 1997; Luintel \& Khan, 1999; Al-Yousif, 2002) revealed bi-directional relationship between financial development and economic growth. Fourth, no causal relationship between financial development and economic growth is found.

Most previous studies (for instance, Schumpeter, 1912; Robinson, 1960; Greenwood \& Jovanovic, 1990; King \& Levine, 1993; Greenwood \& Smith, 1997; Levine, 2005) predicted a linear relationship between finance and growth. However, few studies (for example, Berthelemy \& Varoudakis, 1996; Deidda \& Fattouh, 2002; Deidda, 2006) argued that financial development occurs endogenously as the economy reaches a critical threshold of economic development. If the economy is below the threshold level of financial development, then there is no effect on economic growth, while a sizeable effect occurs above the specific threshold level (Huang \& Lin, 2009).

The threshold effect may either relate to the level of economic development or with financial development across countries (Bose \& Cothren, 1997; Law \& Singh, 2014; Samargandi, Fidrmuc, \& Ghosh, 2015; Zhu, Asimakopoulos, \& Kim, 2020). In particular, higher financial development may not exert a positive impact on economic growth unless a certain level of financial development is reached. Recent studies (such as Law, Azman-Saini, \& Ibrahim, 2013; Arcand, Berkes, \& Panizza, 2015; and Samargandi, Fidrmuc \& Ghosh, 2015) detected that non-linear relationships between financial development and economic growth is dependent on mediating structural factors, including economic institutions. ${ }^{i}$ Likewise, Swami (2017) discovered that the association of financial development with economic growth was moderated by the negative impacts of inflation, interest rate, population dependence, and positive mediated effect of trade openness. Ibrahim and Alagidede (2018) found that the finance-growth relationship is a non-linear and inverted U-shaped. Similarly, Swamy and Dharani (2020) discovered inverted U-shaped relationship between financial development and economic growth with estimated tripping point was at $141 \%$ of GDP. They found that surpassing the threshold level results deceleration in economic growth.

Keeping the importance of finance-growth nexus, the Government of Pakistan embarked on a series of financial sector reforms in the early 1990s. The objective of these reforms was to create a level-playing field for the financial institution by eliminating entry barriers and accelerating competition among the financial institutions, removing distortions and financial market's segmentation, eliminating direct and subsidized credit programs and strengthening the supervisory role of the State Bank of Pakistan (Khan \& Khan, 2011; Naveed \& Mahmood, 2019). These reforms have changed the financial spectrum. These structural shifts may distort the linear relationship between financial development and economic growth and justify the use of the non-linear methodology to analyze finance-growth nexus. The non-linear relationship suggests that economic growth may respond differently to the level of financial development when it remains below or above the certain threshold level. In other words, changes in financial development policies might influence the level of financial development and economic growth differently in a different state of policy intervention (Deidda \& Fattouh, 2002; Demetriades \& Law, 2006; Tran \& Nguyen, 2020).

Several studies on finance-growth nexus are available in Pakistan (for instance, Khan, Qayyum, \& Sheikh, 2005; Naveed \& Mahmood, 2019). However, to the best of our knowledge, no study employed the threshold regression approach to examine the impact of financial development on economic growth. The majority of previous studies provided strong positive evidence of linear relationship on finance-growth nexus. However, the proposition of linear relationship between financial development and economic growth is restrictive, especially when policy intervention occurs in the economy (Ibrahim, 2015). Recent empirical literature highlighted the importance of non-linear relationships between financial development and economic growth (Deidda \& Fattouh, 2002; Kumar \& Paramanik, 2020; Rahman, Khan, \& Charfeddine, 2020). However, empirical research on non-linear relationship between financial development and economic growth with respect to Pakistan is scant. Thus, the present study attempts to examine the impact of financial development on economic growth in Pakistan under the threshold modeling framework.

Against the above backdrop, this study contributes to the existing literature by focusing on finance-growth nexus using the threshold model. This model is useful to determine whether too much finance is beneficial (harmful) for economic growth? This question entails much importance for countries like Pakistan where resources are scarce. Secondly, the present study uses broad-based financial development index (FDI) constructed by the International Monetary Fund (2018) as a proxy of financial development, which covers both aspects of the financial development, that is, financial institutions and financial markets. Most importantly, this index captures the financial depth, financial access and financial efficiency of financial institutions and markets. Thus, FDI is the most comprehensive index that captures 
banks, pension funds, mutual funds, insurance market, debt and securities market and equity market. The findings have potentially important implications for the financial managers and regulators for devising prudent investment and economic growth strategies. Previous studies on Pakistan mainly focused on banking sector variable(s). But this study overcomes the issue of financial structure and focuses on both the financial institutions and financial markets as financial development indicators. We used time-series data to formulate the country-specific policies rather than general information about finance-growth nexus. Besides, this study also provides non-linear estimations of finance-growth nexus in Pakistan to examine the effects of high-level (low-level) financial development on economic growth.

The rest paper is organized as Section 2 reviews relevant literature on finance-growth nexus. Section 3 deals with the model, data, and methodology. Section 4 discusses empirical results, while section 5 recapitulates concluding remarks and outlines policy implications.

\section{Literature Review}

The academic discussion on finance-growth nexus was started when Schumpeter (1912) recognized the role of finance in economic growth process. He argued that financial development contributes to economic growth through capital accumulation and technological innovations. Afterward, McKinnon (1973) and Shaw (1973) asserted the positive role of financial development in economic growth process. In relation to the finance-growth nexus, Patrick (1966) proposed "stages of development" hypothesis that considers supply-leading and demand-following hypotheses. The supply-leading hypothesis stated that financial development plays an important role to sustain economic growth through pooling of resources, risk management and intermediary functions (Levine, 1997). This hypothesis was tested by several researchers using the panel, cross-sectional and timeseries data and found mixed results. For instance, Luintel and Khan (1999) found significant support for the validity of the supply-leading hypothesis in 10 developing countries. De-Gregorio and Guidotti (1995) detected a positive relationship between financial development and economic growth in cross-sectional data and a negative relationship in panel data for Latin American countries.

High level of financial liberalization and poor banking regulations were the main reason behind the negative relationship. On the other hand, the demand-following hypothesis advocated the unidirectional causality from economic growth to financial development. Robinson (1952) argued that financial development followed the enterprise at the initial stage of financial development. Kuznets (1955) supported this argument and found that the nature of economic cycle significantly affected financial development.
Considering the endogenous growth framework, Romer (1986) and Lucas (1988) also argued that financial sector significantly contributed to economic growth through mobilizing savings, efficient allocation of capital resources, minimizing information, monitoring and transaction costs, facilitating exchange of goods and services and diversifying risks. The demand-following hypothesis was acknowledged by many researchers (for example. Khan, Qayyum, \& Sheikh, 2005; Ang \& McKibbin, 2007; Rehman \& Cheema, 2013; Khan, Ahmed, \& Bibi, 2018). They concluded that financial development acts as a main engine of economic growth.

One strand of literature identified a bi-directional relationship between finance and growth. For instance, Greenwood and Jovanovic (1990) argued that financial development promotes investment and economic growth, which in turn spurs financial development.

Few studies emphasized bank credit channel and concluded that financial development can boost or deteriorate economic growth depending on the type of bank credit extended (Arestis \& Demetriades, 1997; Beck, Buyukkarabacak, Rioja, \& Valev, 2012; Sassi \& Gasmi, 2014). In particular, Beck, Buyukkarabacak, Rioja, and Valev (2012) argued that positive impact of financial development on economic growth is mainly determined by enterprise credit rather than consumer credit. Another strand of the literature concluded no relationship between financial development and economic growth. For example, Lucas (1988) argued that financial development is not a determinant of economic growth because as the economy reached a steady-state level, excess capital has no significant impact on economic growth. Many researchers (for example, Kar, Nazlıoglu, \& Agir, 2011; Ali, 2014; Ibrahim \& Alagidede, 2018) concluded that the impact of financial development on economic growth in developing countries is inconclusive.

The empirical literature provides mixed delineation with respect to the impact of financial development on economic growth. For instance, Herwartz and Walle (2014) and Pradhan, Arvin, and Bahmani (2018) found positive relationship between financial development and economic growth. On the other hand, Narayan and Narayan (2013) and Ductor and Grechyna (2015) detected a weak or negative relationship between financial development and economic growth. Chong, Mody and Sandoval (2017) observed that negative relationship between financial development and economic growth has become stronger since 1990 in Europe, which was consistent with the fact that growth of financial system declined economic growth. Findings by Demetriades and Rousseau (2017) indicated that bank regulations and banking supervision exerted a significant effect on financegrowth relationship. Naveed and Mahmood (2019) found a positive and significant impact of internal financial liberalization on economic growth in the long-run, while said relationship turned to be negative in the short-run. 
Recent studies indicated that higher financial development may strengthen economic growth before a certain threshold of financial development is reached (Samargandi, Fidrmuc, \& Ghosh, 2015). Law and Singh (2014) concluded that finance is good for economic growth only up to a certain limit, and more finance beyond a limit may not be good for the economy. In the same vein, few concluded (Deidda \& Fattouh, 2002; Arcand, Berkes, \& Panizza, 2015) that finance exerted a negative impact on economic growth when the level of financial development remains below a certain threshold level. Samargandi, Fidrmuc, and Ghosh (2015) detected an inverted U-shaped relationship between financial development and economic growth in 52 middle-income countries. Alaabed and Masih (2016) investigated the finance-growth threshold for the Malaysian economy and found that expansion of credit has negative impact on economic growth. More recently, Zhu, Asimakopoulos, and Kim (2020) investigated 50 countries to address the question of whether too much finance is effective in finance and innovation-led growth nexus. They found small or even insignificant impact of innovation in the countries having higher level of financial development. Besides, marginal effect of innovation on economic growth is found negatively related to financial development. Similarly, Aluko and Ibrahim (2020) investigated 28 SubSaharan African countries to find the threshold between institutions and finance-growth nexus. They found distinct behavior of institutions in finance-growth relationship. They used different institutional proxies as threshold variable and found that when International Country Risk Guide (ICRG) dataset was used the financial development does not spur economic growth below the optimal level of institutions and vice-versa. Surprisingly, they found that growth spurring effects of finance are higher for such countries having low institutional quality than high institutional quality.

With respect to Pakistan, the majority of studies (for instance, Khan, Qayyum, \& Sheikh, 2005; Tahir, 2008; Khan, 2008; Jalil \& Ma, 2008; Rehman \& Cheema, 2013; Naveed \& Mahmood, 2019) used linear modeling technique to investigate finance-growth nexus. However, these studies ignored the asymmetric relationship, while investigating finance-growth nexus. Only Rahman, Khan, and Charfeddine (2020) confirmed that the behavior of financial development is heterogeneous in pre-and post-reforms periods. However, they ignored the possibility of threshold existence in financegrowth relationship.

From the above literature survey, we deduced that most of the empirical work used linear models to predict the finance-growth relationship in Pakistan. However, Maki (2008) showed that using linear models to interpret nonlinear relationships may lead to poor inferences. Since the financial sector of Pakistan adopted financial reforms in the 1990 s, it is expected that economic growth does not respond monotonically in the pre-and post-reform periods. Therefore, this study considers non-linear aspect of finance-growth nexus in Pakistan using the threshold modeling approach.

\section{Model, Data, And Methodology}

The theoretical framework of this study stems from endogenous growth theory. Several empirical studies highlighted that financial development affects economic growth through capital accumulation and technological innovations. Our modeling approach is based on endogenous growth theories propounded by Lucas (1988), Romer (1986) and Pagano (1993). Following Ang (2011) and Chong, Mody, and Sandoval (2017), we consider following aggregate production function:

$$
Y_{t}=A_{t} K_{t}^{\alpha 1} L_{t}^{\alpha 2} e^{\varepsilon t}
$$

Where, $Y_{t}$ is real GDP at time $t$ proxied for economic growth, $A_{t}$ is total factor productivity $(T F P)$ at time $t, K_{t}$ is physical capital at time t, $L_{t}$ is employed labor force at time t, $\alpha_{1}$ and $\alpha_{2}$ are production elasticities with respect to physical capital and employed labor force respectively, while $\varepsilon_{t}$ is error term. The log-linear form of equation (1) can be written as:

$$
\operatorname{Ln} Y_{t}=\operatorname{Ln} A_{t}+\alpha 1 \operatorname{Ln} K_{t}+\alpha 2 \operatorname{Ln} L_{t}+\varepsilon_{t}
$$

Assume that total factor of production $\left(A_{t}\right)$ is determined by financial sector development, consumer price index, government expenditure as a percentage of GDP and trade openness. Following Anwar and Sun (2011), we specify TFP determinants as follows:

$$
\begin{aligned}
& L n A_{t}=\gamma_{0}+\gamma_{1} L n F D_{t}+\gamma_{2} \operatorname{LnCPI}_{t} \\
& +\gamma_{3} \operatorname{LnGEX} X_{t}+\gamma_{4} \operatorname{LnTO}_{t}
\end{aligned}
$$

Substituting equation (3) into equation (2), we get the following equation.

$$
\begin{aligned}
\operatorname{Ln} Y_{t} & =\beta_{0}+\beta_{1} \operatorname{LnFD}_{t}+\beta_{2} \operatorname{LnK}_{t}+\beta_{3} \operatorname{LnL}_{t} \\
& +\beta_{4} \operatorname{LnTO}_{t}+\beta_{5} \operatorname{Ln} G E X_{t}+\beta_{6} I N F_{t}+\varepsilon_{t}
\end{aligned}
$$

Where $F D_{t}$ measures financial development at time t, $C P I_{t}$ is inflation rate at time $t, G E X_{t}$ is government expenditures relative to GDP at time $t$ and $T_{t}$ is trade openness relative to GDP at time $t$.

In equation (5), $F D_{t}$ is likely to have a positive effect on economic growth since it facilitates saving and investment decisions. Besides, financial sector also facilitates investment opportunities in equity market. Other sectors such as insurance sector, mutual fund and debt and securities market also contribute to the financial sector development. 
Trade openness $\left(T O_{t}\right)$ which is measured by the sum of exports and imports as a percentage of GDP is expected to exert positive impact on TFP and hence economic growth. However, there is also possibility of negative effect of trade openness on TFP and economic growth in case of developing countries. Trade openness is expected to behave negatively with economic growth in Pakistan owing to major share of exports relative to imports. The impact of $G E X_{t}$ on economic growth in developing countries is generally negative due to bureaucratic inefficiency. Durham (2004) argued that public spending financed through tax increase can deteriorate economic performance due to input costs increase, which in turn exerted a negative impact on economic growth. However, we expect positive signs of government expenditures due to bureaucratic reforms in Pakistan. An increase in $I N F_{t}$ rises macroeconomic uncertainty, which is expected to exert a negative impact on TFP, and hence economic growth. Following Ibrahim and Alagidede (2018), we can rewrite equation (4) as:

$$
\operatorname{Ln} Y_{t}=\beta_{0}+\beta_{1} \operatorname{LnFD}+\delta_{i} \operatorname{Ln} X_{t}+\varepsilon_{t}
$$

Where $X_{t}$ is a vector of non-financial variables such as physical capital proxied by the gross fixed capital formation relative to GDP, labor force, inflation rate, trade openness and government consumption expenditure relative to GDP. The main objective of this study is to examine the non-linear impact of finance on growth using the threshold model. In non-linear setup, the response of financial development to economic growth is expected to be different in different regimes.

\subsection{Data}

The present study uses annual data for the period 19802017. The World Bank's World Development Indicators $(W D I)$ and International Monetary Fund (IMF) are the main data sources. In this study, we used the FDI developed by Svirydzenka (2016) and updated by IMF since Adu, Marbuah and Mensah (2013) argued that a single proxy of financial development is not enough to capture the whole impact of financial development on macroeconomic variables. The FDI captures the access, depth, and efficiency of the financial institutions and financial markets. Financial institutions include banking and insurance sector, while financial markets include equity and bond markets, and other nonbanking financial institutions. Thus, FDI is broader in extent that captures wide-ranging aspects of financial sector. Figure 1 depicts the trend of FDI along with its two components, that is, financial institution index (FII) and financial market index (FMI) over the period 1980 to 2017.

It is evident from Figure 1 that the contribution of FMI towards FDI was negligible till 1996, while FII was main contributor from 1980-1996. However, this trend reversed after 1996 when financial markets in Pakistan were operating under liberal macroeconomic environment. After 1996, FMI surpassed FII and peaked in 2007, thereafter contribution of FMI followed declining trend and reached its minimum level in 2014. The spurts and reversals were observed in FDI due to the adoption of financial liberalization policies. After 2007, the FDI is showing decreasing trend which indicating backtrack of financial sector reforms due to global financial crisis of 2007-08 and European debt crisis of 2011. This indicates that the role of FMI in enhancing FDI is crucial, therefore, more liberalization of financial markets may boost overall financial development in Pakistan.

The real GDP $\left(Y_{t}\right)$ is used as a proxy of economic growth following Samargandi, Fidrmuc, and Ghosh (2015). Physical capital $\left(K_{t}\right)$ is used to measure domestic investment level by utilizing the information on gross fixed capital formation as a percentage of GDP. The employed labor force is used as proxy of labor. Inflation $\left(I N F_{t}\right)$ is calculated as the annual percentage change in the consumer price index and it captures macroeconomic stability. Trade openness

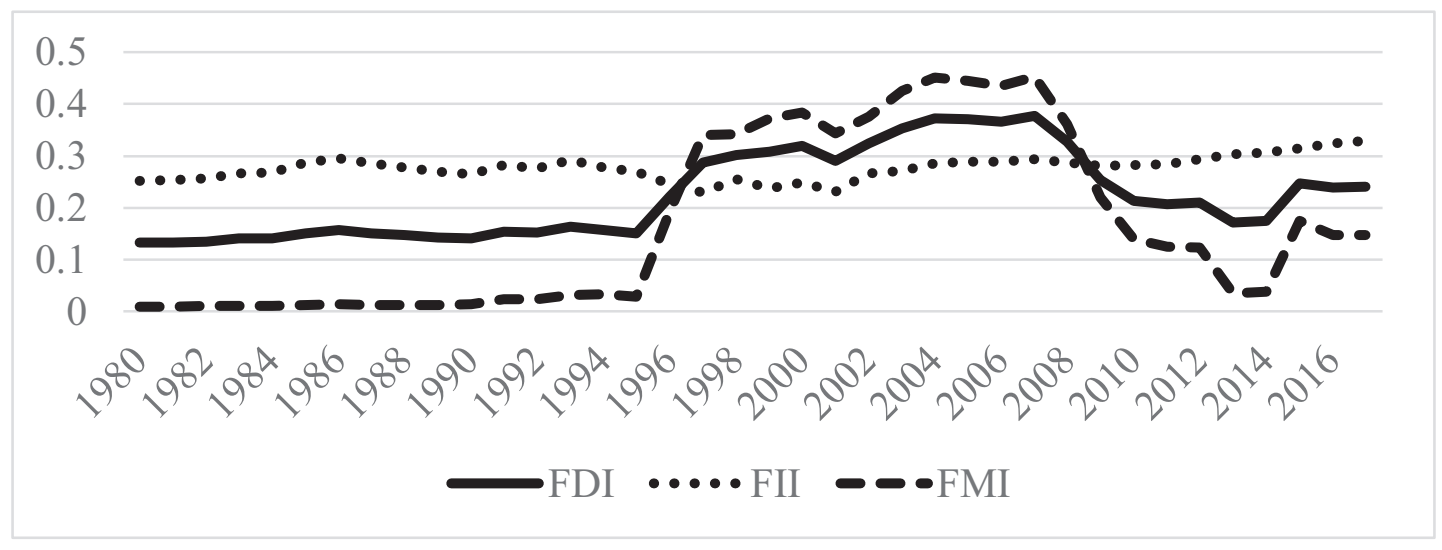

Figure 1: Trend of Financial development index 
Table 1: Summary statistics

\begin{tabular}{|l|c|c|c|c|c|c|c|}
\hline & $\mathbf{L n Y}_{\mathbf{t}}$ & $\mathbf{F D I}_{\mathbf{t}}$ & $\mathbf{L n K}_{\mathbf{t}}$ & $\mathbf{L n L}_{\mathbf{t}}$ & $\mathbf{L n T O}_{\mathbf{t}}$ & $\mathbf{L n G E X}_{\mathbf{t}}$ & $\mathbf{I N F}_{\mathbf{t}}$ \\
\hline Mean & 29.37 & 0.22 & 2.77 & 3.63 & 3.51 & 2.40 & 8.16 \\
\hline Max. & 30.15 & 0.38 & 2.96 & 4.08 & 3.66 & 2.82 & 20.29 \\
\hline Min. & 28.44 & 0.13 & 2.53 & 3.18 & 3.23 & 2.05 & 2.53 \\
\hline Std. Dev & 0.48 & 0.08 & 0.11 & 0.29 & 0.10 & 0.18 & 3.89 \\
\hline Skewness & -0.21 & 0.53 & -0.61 & 0.17 & -0.96 & 0.13 & 0.71 \\
\hline Kurtosis & 1.99 & 1.82 & 2.41 & 1.65 & 3.74 & 2.86 & 3.64 \\
\hline Jarque-Bera & 1.89 & 4.04 & 2.89 & 3.05 & 6.67 & 0.14 & 3.81 \\
\hline
\end{tabular}

Table 2: Correlation analysis

\begin{tabular}{|c|c|c|c|c|c|c|c|}
\hline Correlation & $\operatorname{LnY}_{t}$ & $\mathrm{FDI}_{\mathrm{t}}$ & LnK $_{t}$ & $\mathrm{LnL}_{\mathrm{t}}$ & LnTO $_{t}$ & LnGEX & INF $_{t}$ \\
\hline $\mathrm{LnY}_{\mathrm{t}}$ & 1.00 & & & & & & \\
\hline $\mathrm{FDI}_{\mathrm{t}}$ & $0.58^{* * *}$ & 1.00 & & & & & \\
\hline $\mathrm{LnK}_{\mathrm{t}}$ & $-0.62^{*+*}$ & -0.20 & 1.00 & & & & \\
\hline $\mathrm{LnL}_{\mathrm{t}}$ & $0.98^{* * *}$ & $0.54^{* * * *}$ & $-0.68^{* * *}$ & 1.00 & & & \\
\hline LnTO $_{t}$ & $-0.53^{*+* x}$ & $-0.32^{\text {** }}$ & $0.64^{* * * *}$ & $-0.56^{* *+*}$ & 1.00 & & \\
\hline LnGEX $_{t}$ & $-0.37^{* *}$ & $-0.69^{* * *+}$ & $0.34^{* *}$ & $-0.41^{* *}$ & $0.43^{* * *+}$ & 1.00 & \\
\hline $\mathrm{INF}_{\mathrm{t}}$ & 0.002 & -0.14 & $0.27^{*}$ & 0.02 & $0.55^{* * * *}$ & 0.12 & 1.00 \\
\hline
\end{tabular}

Note: ${ }^{* * *},{ }^{* *}$ and ${ }^{*}$ indicates significant at $1 \%, 5 \%$ and $10 \%$ level of significance based on t-statistics.

represents the significance of international factors in affecting economic activities (Huchet-Bourdon, Mouel \& Vijil, 2018). Trade openness $T O_{t}$ is calculated as the sum of exports and imports as a percentage of GDP. Government expenditure as a percentage of $G D P(G E X)$ is used to measure the size of government and bureaucratic efficiency. It also accounts for investment in physical capital, which may significantly affect economic growth.

Table 1 reports summary statistics of the variables. The mean value of real GDP was 29.37. The average value of FDI was 0.22 , indicating that financial development contributes positively to economic growth. Similarly, mean values of other variables are also found positive. The mean value of the labor force is relatively higher than physical capital showing that Pakistan is a labor-intensive country and the role of labor is relatively larger than physical capital. Statistics also indicate that the standard deviation of inflation was 3.89 , indicating high volatility in consumer prices, which in turn increases macroeconomic uncertainty. Additionally, standard deviation of financial development was observed to be 0.08 , which reveals that financial development is least volatile than other variables under investigation. The trade openness and inflation rate have relatively heavier tails as compared to other variables.

Table 2 gives pair-wise correlation among the variables. The real GDP has negative correlation with physical capital,
Table 3: Results of BDS Test

\begin{tabular}{|c|c|c|c|}
\hline Dimension & BDS statistic & Z-statistic & p-value \\
\hline 2 & 0.08 & 9.31 & $0.000^{* * *}$ \\
\hline 4 & 0.14 & 7.72 & $0.000^{* * *}$ \\
\hline 6 & 0.13 & 6.80 & $0.000^{* * *}$ \\
\hline
\end{tabular}

Note: ${ }^{* *}$ indicates significance at $1 \%$ level of significance. P-values based on bootstrap (100,000 replications).

trade openness and government expenditures, whereas all other variables have positive correlation with real GDP. Interestingly, FDI has positive correlation with real GDP, which reveals that better quality financial system enhances economic growth. Labor force and physical capital have highest correlation with real GDP, while FDI has negative correlation with physical capital, trade openness, government expenditures and inflation rate.

To examine the non-linearity between finance and growth, we employed the BDS (Brock, Dechert, \& Scheinkman, 1987) test (see Table 3). The BDS test is useful in detecting non-linearity under the null hypothesis that residuals are independent and identically distributed (iid).

BDS test confirms that finance-growth nexus is nonlinear since selected dimensions are significant at $1 \%$ level 
of significance. Therefore, data suggest that the use of linear statistical techniques may provide spurious results. Hence, non-linear technique may provide better estimates as compared to linear estimation method. To this end, threshold regression model provides useful information with respect to the impact of low-FD and high-FD on economic growth.

\subsection{Threshold Model}

The vast literature on finance-growth nexus can be characterized by the inconclusiveness of empirical findings. This inconclusiveness may arise from non-linear relationship between finance and growth. This study hypothesizes that repressive and liberal financial sector may have differing effects on economic growth depending on whether financial development surpasses a critical threshold level. For this reason, threshold model developed by Hansen (1999) is employed, which allows non-linear relationship between dependent and independent variables, which are determined by the threshold level (Bilman \& Karaoglan, 2020). The threshold model is superior as compared to other models because it not only computes nonlinear function but also facilitates estimation of threshold value rather than fixing them at any arbitrary value (Swamy \& Dharani, 2020). Following Hansen and Seo (2002), functional form of equation (5) in terms of threshold regression model can be expressed as:

$$
Y_{t}, q_{t}, X_{t} ; 1 \leq t \leq T
$$

Where $Y_{t}$ is dependent variable at time $\mathrm{t}, q_{t}$ is a threshold variable, and $X_{t}$ is a set of variables hypothesized to affect economic growth. The structural form of equation (6) for a single threshold can be written as:

$$
Y_{t}=\left\{\begin{array}{l}
\beta_{0}+\beta_{1} F D_{t}+\delta_{i} X_{t}+u_{t} \text { if } F D_{t} \leq \lambda \\
\beta_{0}+\beta_{2} F D_{t}+\delta_{i} X_{t}+u_{t} \text { if } F D_{t}>\lambda
\end{array}\right.
$$

Where $\beta_{0}$ is intercept term, $u_{t}$ is error term which is assumed to be independent and identically distributed (iid), $\lambda$ is threshold value, while $F D_{t}$ is regime-dependent regressor.

Since the focus of this study is to examine the effects of $F D_{t}$ on economic growth conditional on $F D_{t}$. Therefore, the effect of $F D_{t}$ on economic growth can be investigated under two possible cases: when $F D_{t}$ is below or above the estimated threshold parameter $(\lambda)$, an estimated value of $F D_{t}$ that splits sample into low- $F D_{t}$ and high- $F D_{t}$ regimes. After estimating threshold parameter $\hat{\lambda}$, we estimated regimedependent coefficients $\beta_{1}$ and $\beta_{2}$, which coincides with low$F D_{t}$ and high- $F D_{t}$ regimes, respectively (Tran, 2018). Once threshold value is identified, we can test significance of threshold effect under null hypothesis of no threshold effect
$\left(H_{0}: \beta_{1}=\beta_{2}\right)$ against alternative hypothesis of one threshold $\left(H_{1}: \beta_{1} \neq \beta_{2}\right)$ using Likelihood ratio test. If F-statistic is greater than critical value, the null of no threshold is rejected. To check robustness of threshold regression model, we employed quantile regression model.

\subsection{Quantile Regression}

The quantile regression is popular approach for conditional distribution instead of conditional mean distribution, which was presented by Koenker and Bassett (1978). We employed quantile regression with $0.25,0.50$, and 0.75 quantiles of conditional distribution. The quantile regression is based on minimizing of sum of squared residuals which estimate conditional mean function.

The quantile regression is useful for robustness as compared to other methods. Andini and Andini (2014) argued that quantile regression is useful to examine the changing shape and shifting location of conditional distribution. Additionally, estimates of quantile regression are more robust in the presence of outliers. Likewise, Mello and Perrelli (2003) argued that quantile regression provides useful information that how macroeconomic variables react to changes in policy variables. This study uses three different quantiles of financial development index to examine how economic growth responds to various quantiles of financial development. Furthermore, we examine the way by which finance-growth nexus differs at tail of conditional distribution by considering graphs corresponding to different quantile between $10^{\text {th }}$ and the $90^{\text {th }}$.

\section{Empirical Results}

We consider $F D_{t}$ as regime-dependent variable, while rest variables are treated as regime-independent. Because of small sample size, we assume only two-regime threshold model that coincides with the low- $F D_{t}$ and high- $F D_{t}$ regime. Intuitively, two-regime model based on single threshold may perform better and easy to elaborate empirical findings. We have running several regressions using Ordinary Least Squares (OLS) on equation (7) to estimate threshold parameter. Afterward, we obtained the sum of squares residuals $S(\lambda)$ and choose that threshold value which makes the $S(\lambda)$ smallest, that is, $\hat{\lambda}=\arg \min (\lambda)$. Thus, there exists a single threshold and the computed threshold parameter $\hat{\lambda}$ is 0.151 . The computed threshold value $(0.151)$ will split the financial development data into two subsamples. The computed F-statistic is 22.29 which is higher than critical value of 8.58 , indicating the rejection of null hypothesis of no threshold.

The results of finance-growth nexus based on the threshold estimation are reported in Table 4. It can be seen from results that in low- $F D_{t}$ regime financial development 
has a negative and statistically significant effect on economic growth if it is less than the threshold value of 0.151 . The estimated threshold value of 0.151 is fairly low in finance-growth literature as compared to earlier studies. The previous studies have estimated finance-growth threshold value between 0.53 and 1.00 . To this end, using a panel of 87 countries Law and Singh (2014) estimated threshold value of 0.88 and 0.91 respectively for private sector credit to GDP and liquid liabilities to GDP. Likewise, Samargandi, , Fidrmuc, and Ghosh (2015) investigated 52 middle-income counties and found 0.92 as financial development threshold value. Whereas Zhu, Asimakopoulos, and Kim (2020) found the values of threshold as 0.39 when used domestic credit variable, 0.44 for private credit and banking credit, and 0.61 when used liquidity as proxy for financial development. The lower value of threshold in our case may be due to a single country estimation, small size of financial as well as real sector and relatively low quality institutions.

The coefficient of financial development in low- $F D_{t}$ regime is -0.74 which suggests that a unit-percentage point increase in financial development would reduce economic growth by $0.74 \%$. On the other hand, the impact of financial development on economic growth is turned to be positive and statistically significant when it surpasses threshold value of 0.151 in high- $F D$ regime. The result reveals that economic growth increases by $0.38 \%$ in response to a unit-percentage point increase in the level of financial

Table 4: Results of finance-growth nexus: Threshold model (1980-2017)

\begin{tabular}{|c|c|c|}
\hline \multicolumn{3}{|l|}{ Dependent variable: $\mathrm{LnY}_{\mathrm{t}}$} \\
\hline \multicolumn{3}{|c|}{ Threshold estimate of $\mathrm{FDI}_{\mathrm{t}}=0.151$} \\
\hline Independent variables & Coefficient & t-value \\
\hline Low-FD, regime: $F D I_{t}$ & -0.74 & $-1.68^{*}$ \\
\hline High-FD regime: $F D_{t}$ & 0.38 & $2.01^{* *}$ \\
\hline \multicolumn{3}{|l|}{ Non-threshold variables } \\
\hline Constant & 22.39 & $23.66^{* \star *}$ \\
\hline $\mathrm{LnK}_{\mathrm{t}}$ & 0.28 & $2.05^{\star \star}$ \\
\hline $\mathrm{LnL}_{\mathrm{t}}$ & 1.56 & $18.43^{* * *}$ \\
\hline $\mathrm{LnTO}_{\mathrm{t}}$ & -0.02 & -0.16 \\
\hline $\operatorname{LnGEX}_{t}$ & 0.26 & $3.16^{* * *}$ \\
\hline $\mathrm{INF}_{\mathrm{t}}$ & -0.004 & -1.14 \\
\hline Adj $R^{2}=0.98$ & $S S R=0.12$ & $\begin{array}{c}\text { F-stat }=311.17 \\
{[0.000]^{* * *}}\end{array}$ \\
\hline $\begin{array}{l}\text { Jarque-Bera = } \\
0.73[0.695]\end{array}$ & $\begin{array}{l}\text { LM-F = } 5.59 \\
{[0.009]^{* * *}}\end{array}$ & $\begin{array}{c}\text { Hetro-F }=1.59 \\
{[0.210]}\end{array}$ \\
\hline
\end{tabular}

Note: ${ }^{* *},{ }^{* *}$ and * denotes significant at $\%, 5 \%$ and $10 \%$ level of significance. Figure in [.] are p-values. development in high- $F D_{t}$ regime. Thus, differential impact of finance on growth in both regimes confirms U-shaped impact of financial development on economic growth in Pakistan. The magnitude associated with $F D_{t}$ pinpoints that negative impact of financial development in low- $F D_{t}$ regime is more severe than benefit of high- $F D_{t}$ regime. This suggests that Pakistan must attain the financial development above the threshold level for an effective role in economic growth.

These findings are in line with empirical literature that as level of financial sector deteriorates, economies of scale benefit from the lower costs and higher return of capital, thereby slowing economic growth. On the other hand, greater level of financial development boosts economic growth. These results are inconsistent with Khan, Qayyum, and Sheikh (2005), Khan (2008), and Naveed and Mahmood (2019) in case of Pakistan. Our results also differ from Law and Singh (2014), Arcand, Berkes, and Panizza (2015), and Ibrahim and Alagidede (2018). However, our findings are consistent with Deidda and Fattouh (2002), Henderson, Papageorgiou, and Parmeter (2013), Ruiz (2018), and Rahman, Khan, and Charfeddine (2020). These studies reported a higher impact of financial development on economic growth according to the income levels in various economies. The main reason could be that financial development directed towards investment activities promotes economic growth, but consumption loans move towards opposite direction (Hung, 2009).

Among non-threshold variables, physical capital, labor force and government expenditure exerts positive and significant impact on economic growth. The results indicate that real GDP would increase by $0.28 \%$ and $1.56 \%$ in response to a $1 \%$ increase in physical capital and labor force. Particularly, increase in physical capital may increases productive capacity of goods and services at lower cost, which leads higher production hence higher economic growth. Likewise, government expenditure also exerts positive effect on economic growth. The result indicates that a $1 \%$ increase in government spending would increase real GDP by $0.26 \%$. This implies that government expenditure on public services and investment in infrastructure significantly enhances economic growth. Although, government expenditures are enhancing economic growth, but small magnitude (0.26) signals bureaucrats for better and productive use of government expenditures. With efficient bureaucratic role, government expenditures can further contribute to economic growth in Pakistan. The result also indicates that inflation rate and trade openness exert insignificant negative impact on real GDP.

\subsection{The Quantile Regression}

To check the robustness of threshold results and to further understand behavior of finance-growth relationship, we employed quantile regression technique to examine the 
response of economic growth to variant levels of financial development. To this end, we used $0.25^{\text {th }}, 0.50^{\text {th }}$ and $0.75^{\text {th }}$ quantile of real GDP distribution. Table 5 reports results of the whole period, $25^{\text {th }}$ and $75^{\text {th }}$ quantiles. The $25^{\text {th }}$ quantile of real GDP distribution representing low-growth regime, while $75^{\text {th }}$ quantile showing high-growth regime.

Table 5 shows that impact of FDI on economic growth is quite different between low-growth and high-growth regime. This can be seen from coefficient magnitude, sign and significance of each variables. For example, estimated $25^{\text {th }}$ quantile coefficient of FDI is eight times higher than that of the $75^{\text {th }}$ quantile. The result indicates that economic growth would increases by $0.80 \%$ in response to a unit percentage point increase in FDI when $25^{\text {th }}$ quantile is considered, whereas a one-percentage-point increase in FDI leads to a $0.10 \%$ increase in economic growth when the $75^{\text {th }}$ quantile is considered. Besides, the major difference in coefficient of FDI is observed for $25^{\text {th }}, 50$ th and $75^{\text {th }}$ quantiles. The reason may be sensitivity of financial sector with respect to level of economic growth. This heterogeneous response of economic growth to FDI confirms the findings of the threshold regression model. The values of Pseudo $\mathrm{R}^{2}$ confirm that quantile model best fits the data. The effect of FDI on economic growth at different quantiles is depicted in Figure 2.
Figure 2 shows that the impact of FDI on economic growth remains constant up to $60^{\text {th }}$ quantile. Afterward, impact of FDI dropped sharply by about $10 \%$ until the $75^{\text {th }}$ quantile. Thereafter, the impact falls slowly as economic growth increases. Interestingly, we observed that decline in the impact of FDI on real GDP is lesser for highest quantile

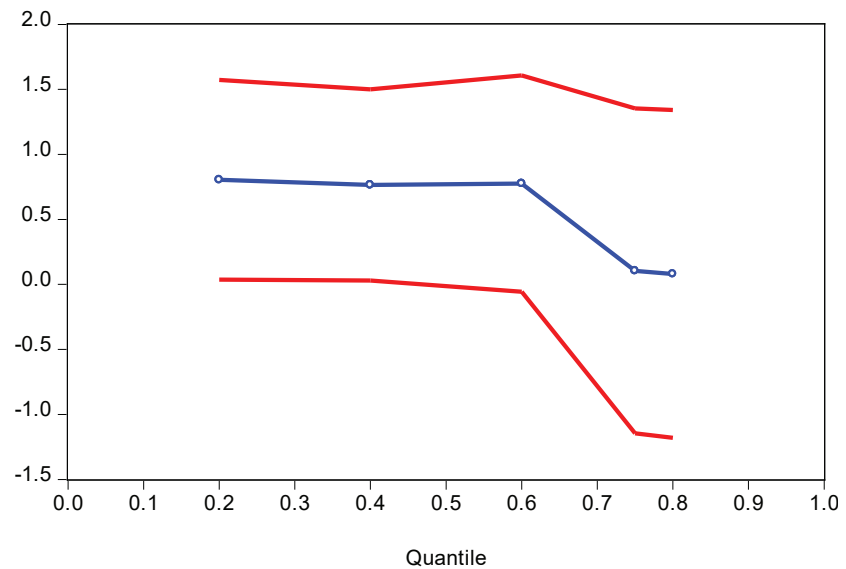

Figure 2: Impact of FDI on real GDP (95\% confidence interval)

Table 5: Quantile regression estimates on finance-growth nexus (1980-2017)

\begin{tabular}{|c|c|c|c|c|}
\hline \multicolumn{5}{|c|}{ Dependent variable: $\mathrm{LnY}_{\mathrm{t}}$} \\
\hline \multirow[t]{2}{*}{ Variable } & \multirow[t]{2}{*}{ OLS } & \multicolumn{3}{|c|}{ Quantile regression } \\
\hline & & 0.50 & 0.25 & 0.75 \\
\hline Constant & $\begin{array}{c}21.36 \\
(18.14)^{* * * *}\end{array}$ & $\begin{array}{c}20.82 \\
(15.77)^{*+* *+}\end{array}$ & $\begin{array}{c}23.34 \\
(23.39)^{*+*+*}\end{array}$ & $\begin{array}{c}22.77 \\
(16.07)^{* * * *}\end{array}$ \\
\hline $\mathrm{FDI}_{\mathrm{t}}$ & $\begin{array}{c}0.55 \\
(2.27)^{* *}\end{array}$ & $\begin{array}{c}0.89 \\
(3.20)^{* * * *}\end{array}$ & $\begin{array}{c}0.80 \\
(6.55)^{* *}\end{array}$ & $\begin{array}{c}0.10 \\
(0.33)\end{array}$ \\
\hline $\operatorname{LnK}_{t}$ & $\begin{array}{c}0.34 \\
(1.63)\end{array}$ & $\begin{array}{c}0.41 \\
(2.66)^{*+*}\end{array}$ & $\begin{array}{l}-0.19 \\
(1.11)\end{array}$ & $\begin{array}{c}0.43 \\
(1.84)^{* *}\end{array}$ \\
\hline $\mathrm{LnL}_{\mathrm{t}}$ & $\begin{array}{c}1.70 \\
(20.06)^{*+* x}\end{array}$ & $\begin{array}{c}1.74 \\
(18.71)^{*+*+}\end{array}$ & $\begin{array}{c}1.58 \\
(23.67)^{k+* *}\end{array}$ & $\begin{array}{c}1.59 \\
(15.78)^{* * * *}\end{array}$ \\
\hline $\operatorname{LnTO}_{t}$ & $\begin{array}{c}0.08 \\
(0.57)\end{array}$ & $\begin{array}{c}0.09 \\
(0.38)\end{array}$ & $\begin{array}{c}-0.08 \\
(-0.49)\end{array}$ & $\begin{array}{c}-0.12 \\
(-0.64)\end{array}$ \\
\hline LnGEX $_{t}$ & $\begin{array}{c}0.22 \\
(2.08)^{* *}\end{array}$ & $\begin{array}{c}0.26 \\
(1.74)^{*}\end{array}$ & $\begin{array}{c}0.36 \\
(4.70)^{*+*+*}\end{array}$ & $\begin{array}{c}0.04 \\
(0.34)\end{array}$ \\
\hline $\mathrm{INF}_{\mathrm{t}}$ & $\begin{array}{l}-0.005 \\
(-1.22)\end{array}$ & $\begin{array}{l}-0.007 \\
(-1.05)\end{array}$ & $\begin{array}{l}-0.002 \\
(-0.59)\end{array}$ & $\begin{array}{c}-0.0005 \\
(-0.10)\end{array}$ \\
\hline Adjusted $\mathrm{R}^{2}$ & 0.98 & - & - & - \\
\hline Pseudo $\mathrm{R}^{2}$ & - & 0.86 & 0.89 & 0.85 \\
\hline
\end{tabular}

Note: ${ }^{* * *},{ }^{* *}$ and ${ }^{*}$ indicates significant at $1 \%, 5 \%$ and $10 \%$ level of significance. Sparsity function is computed using kernel method. Results are robust to other methods such as bootstrap or Siddiqui. 
than lowest quantile. This means that the impact of FDI on economic growth is higher in low-growth regime than that of high growth regime.

The physical capital and labor force appeared to be important variables in influencing economic growth in the $75^{\text {th }}$ quantile. Inflation rate and trade openness exerts insignificant impact on economic growth across all the quantiles. However, government expenditures observed to be significant in $25^{\text {th }}$ quantile.

\section{Conclusion and Policy Implication}

This study provides new insights on the non-linear finance-growth relationship in Pakistan using threshold model during 1980-2017. The result reveals two-regime dependent effects of financial development on economic growth. The said impact is found to be negative when financial development lies below the threshold value of 0.151 in the low- $F D_{t}$ regime. However, financial development significantly contributes to economic growth when level of financial development surpasses the threshold level of 0.151 in the high- $F D_{t}$ regime. This finding indicates that financial development is ineffective in promoting economic growth if it is less than the threshold value. However, when financial development is above the threshold value, economic growth reacts positively to financial development. These findings support the hypothesis that the relationship between finance and growth is inverted U-shaped. The negative impact of FD in low-FD regime is more harmful than benefits of positive impact in high-FD regime. Therefore, Pakistan may maintain minimum threshold level of financial development for its positive contribution in economic growth. Additionally, quantile regression results also confirms heterogeneous response of economic growth to financial development between the $25^{\text {th }}$ and $75^{\text {th }}$ quantiles. The physical capital, labor force and government expenditure appear as important factors enhancing economic growth.

The key policy implications are: financial development exerts asymmetric impact on economic growth. This implies that financial development partially spurs economic growth. It is well documented in the literature that underdeveloped financial sector may be associated with high transaction costs, rigidities, and sub-optimal allocation of resources, which in turn adversely affects overall economic growth. However, as financial development surges above the threshold level, economic growth increases. It means that countries with high financial development may enjoy higher economic growth. In Pakistan, our results reveal that financial development behaves negatively in lowfinancial development regime, therefore, revamping of financial sector policies are required. In order to improve the efficiency of financial sector, policymakers may design strategies to enhance credit allocation, strengthen regulatory and institutional frameworks to make it possible for the financial sector to generate positive impacts on economic growth. Besides financial development, physical capital, labor force, and government expenditure are key variables contributing to economic growth.

Although this study provides important insights on finance-growth nexus using the threshold model. However, it would be more insightful to investigate region-specific thresholds in the finance-growth nexus. It would also be more interesting to investigate the responses of economic growth to domestic financial development using the regimeswitching model. We leave this possibility for future research.

\section{References}

Adu, G., Marbuah, G., \& Mensah, J. T. (2013). Financial development and economic growth in Ghana: Does the measure of financial development matter? Review of Development Finance, 3(4), 192-203.

Alaabed, A., \& Masih, M. (2016). Finance-growth nexus: Insights from an application of threshold regression model to Malaysia's dual financial system. Borsa Istanbul Review, 16(2), 63-71.

Ali, R. (2014). The role of bank-based finance in economic growth of Pakistan. Middle-East Journal of Scientific Research 22, 8290.

Aluko, O. A., \& Ibrahim, M. (2020). Institutions and the financial development-economic growth nexus in sub-Saharan Africa. Economic Notes, https://onlinelibrary.wiley.com/doi/ epdf/10.1111/ecno.12163.

Al-Yousif, Y. K. (2002). Financial development and economic growth: another look at the evidence from developing countries. Review of Financial Economics, 11(2), 131-150.

Andini, M., \& Andini, C. (2014). Finance, growth and quantile parameter heterogeneity. Journal of Macroeconomics, 40, 308322.

Ang, J. B. (2011). Financial development, liberalization and technological deepening. European Economic Review, 55(5), 688-701.

Ang, J. B., \& McKibbin, W. J. (2007). Financial liberalization, financial sector development and growth: evidence from Malaysia. Journal of Development Economics, 84(1), 215-233.

Anwar, S., \& Sun, S. (2011). Financial development, foreign investment and economic growth in Malaysia. Journal of Asian Economics, 22(4), 335-342.

Arcand, J. L., Berkes, E., \& Panizza, U. (2015). Too much finance? Journal of Economic Growth, 20(2), 105-148.

Arestis, P., \& Demetriades, P. (1997). Finance and growth: Institutional considerations, financial policies, and causality. Zagreb International Review of Economics and Business, 2(1), 37-62.

Beck, T., Buyukkarabacak, B., Rioja, F. K., \&Valev, N. T. (2012). Who gets the credit? and does it matter? household vs. firm 
lending across countries. The B.E. Journal of Macroeconomics, 12(1) 1-46.

Berthelemy, J. C., \& Varoudakis, A. (1996). Economic growth, convergence clubs, and the role of financial development. Oxford Economic Papers, 48(2), 300-328.

Bilman, M. E., \& Karaoglan, S. (2020). Does the twin deficit hypothesis hold in the OECD countries under different real interest rate regimes? Journal of Policy Modeling, 42(1), 205-215.

Bose, N., \& Cothren, R. (1997). Asymmetric information and loan contracts in a neoclassical growth model. Journal of Money, Credit, and Banking, 423-439.

Brock, W. A., Dechert, W. D. \& Scheinkman, J. A. (1987). A test for independence based on the correlation dimension. Working Paper No. 870, Social Systems Research Institute, University of Wisconsin, Madison.

Chong, E. Y. L., Mody, A., \& Sandoval, F. V. (2017). Finance and growth: The direction of causality. VOX, CEPR's Policy Portal. https://voxeu.org/article/finance-and-growth-directioncausality.

De-Gregorio, J., \& Guidotti, P. E. (1995). Financial development and economic growth. World Development, 23(3), 433-448.

Deidda, L. G. (2006). Interaction between economic and financial development. Journal of Monetary Economics, 53(2), 233-248.

Deidda, L., \& Fattouh, B. (2002). Non-linearity between finance and growth. Economics Letters, 74(3), 339-345.

Demetriades, P. O., \& Hussein, K. A. (1996). Does financial development cause economic growth? Time-series evidence from 16 countries. Journal of Development Economics, 51(2), $387-411$.

Demetriades, P. O., \& Law, S. H. (2006). Finance, institutions and financial growth. International Journal of Finance and Economics, 11(3), 245-260.

Demetriades, P. O., Rousseau, P. L., \& Rewilak, J. (2017). Finance, growth, and fragility. Working Paper No. 17/13, University of Leicester.

Demirgus-Kunt, A., \& Maksimovic, V. (2002). Funding growth in bank-based and market-based financial systems: Evidence from firm-level data. Journal of Financial Economics, 65(3), 337363.

Ductor, L., \& Grechyna, D. (2015). Financial development, real sector, and economic growth. International Review of Economics and Finance, 37, 393-405.

Durham, J. B. (2004). Absorptive capacity and the effects of foreign direct investment and equity foreign portfolio investment on economic growth. European Economic Review, 48(2), 285-306.

Fisman, R., \& Love, I. (2002). Financial dependence and growth revisited. Journal of the European Economic Association, 5(23), 470-479.

Greenwood, J., \& Jovanovic, B. (1990). Financial development, growth, and the distribution of income. Journal of Political Economy, 98(5), 1076-1107.
Greenwood, J., \& Smith, B. D. (1997). Financial markets in development, and the development of financial markets. Journal of Economic Dynamics and Control, 21(1), 145-181.

Hansen, B. E. (1999). Threshold effects in non-dynamic panels: Estimation, testing, and inference. Journal of Econometrics, 93(2), 345-368.

Hansen, B. E., \& Seo, B. (2002). Testing for two-regime threshold cointegration in vector error-correction models. Journal of Econometrics, 110(2), 293-318.

Henderson, D. J., Papageorgiou, C., \& Parmeter, C. F. (2013). Who benefits from financial development? New methods, new evidence. European Economic Review, 63, 47-67.

Herwartz, H., \& Walle, Y. M. (2014). Determinants of the link between financial and economic development: Evidence from a functional-coefficient model. Economic Modeling, 37, 417-427.

Huang, H. C., \& Lin, S. C. (2009). Non-linear finance-growth nexus: A threshold with instrumental variable approach 1 . Economics of Transition, 17(3), 439-466.

Huchet-Bourdon, M., Le Mouel, C., \& Vijil, M. (2018). The relationship between trade openness and economic growth: Some new insights on the openness measurement issue. The World Economy, 41(1), 59-76.

Hung, F. S. (2009). Explaining the nonlinear effects of financial development on economic growth. Journal of Economics, 97(1), 41-65.

Ibrahim, M. H. \& Alagidede, P. (2018). Nonlinearities in financial development-economic growth nexus: Evidence from subSaharan Africa. Research in International Business and Finance, 46, 95-104.

Ibrahim, M. H. (2015). Oil and food prices in Malaysia: A nonlinear ARDL. Agriculture and Food Economics, 3(1), 1-14.

Jalil, A., \& Ma, Y. (2008). Financial development and economic growth: Time series evidence from Pakistan and China. Journal of Economic Cooperation, 29(2), 29-68.

Kar, M., Nazlıglu, S., \& Agir, H. (2011). Financial development and economic growth nexus in the MENA countries: Bootstrap panel granger causality analysis. Economic Modeling, 28(1-2), 685-693.

Khan, A., Ahmed, M., \& Bibi, S. (2018). Financial development and economic growth nexus for Pakistan: A revisit using maximum entropy bootstrap approach. Empirical Economics, 1-13.

Khan, M. A. (2008). Foreign direct investment and economic growth: The role of the domestic financial sector. Working Paper No.18, Pakistan Institute of Development Economics.

Khan, M. A., \& Khan, S. A. (2011). Foreign Direct Investment and Economic Growth in Pakistan: A Sectoral Analysis. Working Paper No. 67, Pakistan Institute of Development Economics.

Khan, M. A., Qayyum, A., \& Sheikh, S. A., (2005). Financial development and economic growth: The case of Pakistan. The Pakistan Development Review, 44, 819-837. 
Khan, M. S., \& Senhadji, A. S. (2003). Financial development and economic growth: A review and new evidence. Journal of African Economies, 12(2), 89-110.

King, R. G., \& Levine, R. (1993). Finance and growth: Schumpeter might be right. The Quarterly Journal of Economics, 108(3), 717-737.

Koenker, R., \& Bassett Jr, G. (1978). Regression quantiles. Econometrica: Journal of the Econometric Society, 33-50.

Kumar, K. \& Paramanik, R. (2020). Nexus between Indian economic growth and financial development: A non-linear ARDL approach. Journal of Asian Finance, Economic and Business, 7(6), 109-116. https://doi.org/10.13106/jafeb.2020. vol7.no6.109

Kuznets, S. (1955). Economic growth and income inequality. The American Economic Review, 45(1), 1-28.

Law, S. H., \& Singh, N. (2014). Does too much finance harm economic growth? Journal of Banking \& Finance, 41, 36-44.

Law, S. H., Azman-Saini, W. N. W., \& Ibrahim, M. H. (2013). Institutional quality thresholds and the finance-growth nexus. Journal of Banking \& Finance, 37(12), 5373-5381.

Levine, R. \& Zervos, S. (1998). Stock markets, banks, and economic growth, American Economic Review 88(3), 537-558.

Levine, R. (1998). Financial development and economic growth: Views and agenda. Journal of Economic Literature, 35(2), 688726.

Levine, R. (2005). Finance and growth: Theory and evidence. Handbook of Economic Growth, 1, 865-934.

Lucas, R. (1988). On the mechanics of economic development, Journal of Monetary Economics 22(1), 3-42.

Luintel, K. B., \& Khan, M. (1999). A quantitative reassessment of the finance-growth nexus: Evidence from a multivariate VAR. Journal of Development Economics, 60(2), 381-405.

Masten, A. B., Coricelli, F., \& Masten, I. (2008). Non-linear growth effects of financial development: Does financial integration matter?. Journal of International Money and Finance, 27(2), 295-313.

McKinnon, R. I. (1973). Money and capital in economic development. Washington DC: Brookings Institution.

Mello, M., \& Perrelli, R. (2003). Growth equations: A quantile regression exploration. The Quarterly Review of Economics and Finance, 43(4), 643-667.

Narayan, P. K., \& Narayan, S. (2013). The short-run relationship between the financial system and economic growth: New evidence from regional panels. International Review of Financial Analysis, 29, 70-78.

Naveed, S., \& Mahmood, Z. (2019). Impact of domestic financial liberalization on economic growth in Pakistan. Journal of Economic Policy Reform, 22(1), 16-34.

Pagano, M. (1993). Financial markets and growth: an overview. European Economic Review, 37(2-3), 613-622.
Panizza, U. (2012). Finance and economic development. International Development Policy: Aid, Emerging Economies and Global Policies, 141-160.

Patrick, H. T. (1966). Financial development and economic growth in underdeveloped countries. Economic Development and Cultural Change, 14(2), 174-189.

Pradhan, R. P., Arvin, M. B., \& Bahmani, S. (2018). Are innovation and financial development causative factors in economic growth? Evidence from a panel granger causality test. Technological Forecasting and Social Change, 132, 130-142.

Rahman, A., Khan, M. A., \& Charfeddine, L. (2020). Financial development-economic growth nexus in Pakistan: new evidence from the Markov switching model. Cogent Economics \& Finance, 8(1), 1716446.

Rehman, A., \& Cheema, A. (2013). Financial development and real sector growth in Pakistan. Interdisciplinary Journal of Contemporary Research in Business, 5(1), 618-636.

Robinson, J. (1952). The Generalization of the General Theory, in the Rate of Interest and Other Essays. London: Macmillan.

Romer, P. M. (1986). Increasing returns and long-run growth. Journal of Political Economy, 94(5), 1002-1037.

Ruiz, J. L. (2018). Financial development, institutional investors, and economic growth. International Review of Economics and Finance, 54, 218-224.

Samargandi, N., Fidrmuc, J., \& Ghosh, S. (2015). Is the relationship between financial development and economic growth monotonic? Evidence from a sample of middle-income countries. World Development, 68, 66-81.

Sassi, S., \& Gasmi, A. (2014). The effect of enterprise and household credit on economic growth: New evidence from European Union countries. Journal of Macroeconomics, 39, 226-231.

Schumpeter, J. A. (1912). The theory of economic development: An inquiry into profits, capital, credit, interest, and the business cycle. Cambridge, MA: Harvard University Press.

Seven, U., \& Yetkiner, H. (2016). Financial intermediation and economic growth: Does income matter? Economic Systems, 40(1), 39-58.

Shaw, E. S. (1973). Financial deepening in economic development. New York: Oxford University Press.

Slesman, L., Baharumshah, A. Z., \& Azman-Saini, W. N. W. (2019). Political institutions and finance-growth nexus in emerging markets and developing countries: A tale of one threshold. The Quarterly Review of Economics and Finance, 72, 80-100.

Svirydzenka, K. (2016). Introducing a new broad-based index of financial development. Working Paper No.16(5), International Monetary Fund.

Swami, N. (2017). The effect of non-permanent contractual employment on financial hardship. Working Paper No. 20(17), Melbourne Institute. 
Swamy, V., \& Dharani, M. (2020). Thresholds of financial development in the Euro area. The World Economy, 43(6), 1730-1774. https://doi.org/10.1111/twec.12902

Tahir, M. (2008). An investigation of the effectiveness of financial development in Pakistan. Lahore Journal of Economics, 13(2), 27-44.

Tran, S. H., \& Nguyen, L. T., (2020). Financial development, business cycle and bank risk in Southeast Asian countries. Journal of Asian Finance, Economic and Business, 7(3), 127135. https://doi.org/10.13106/jafeb.2020.vol7.no3.127

Tran, V. T., Walle, Y. M., \& Herwartz, H. (2018). Local financial development and household welfare in Vietnam: Evidence from a panel survey. The Journal of Development Studies, 54(4), 619-640.

Zhu, X., Asimakopoulos, S., \& Kim, J. (2020). Financial development and innovation-led growth: Is too much finance better?. Journal of International Money and Finance, 100, 102083. DOI: 10.1016/j.jimonfin.2019.102083

\section{Endnotes}

iThese studies found positive effect of finance on growth for values below the threshold while positive otherwise.

${ }^{\mathrm{ii}}$ For simplicity, we changed elasticities into Following Ibrahim and Alagidede (2018), Swamy and Dharani (2020), we included inflation rate instead of CPI. Inflation rate and government expenditures are included to capture the impact of monetary policy and fiscal policy on TFP, while trade openness is included to examine the effect of international competitiveness.

${ }^{\text {iii }}$ These studies found positive effect of finance on growth for values below the threshold while positive otherwise.

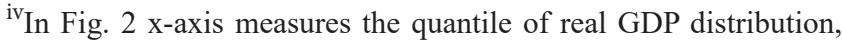
while $y$-axis measures FDI.

${ }^{\mathrm{V}}$ In Fig. 2 x-axis measures the quantile of real GDP distribution, while y-axis measures FDI. 